\title{
Simulation Examination about Heat Balance of Detached House with the Air-based Solar Heating System
}

\author{
Youngjin $\mathrm{Choi}^{1}$ \\ ${ }^{1}$ Platform of Inter/Transdisciplinary Energy Research, Kyushu University, Fukuoka, Japan
}

\begin{abstract}
In this study, it is proposed a heating and hot water system for a house using the air-based solar collection. The performance of existing solar heating system is analyzed by annual simulation and the problems and the effect of thermal characteristics of the system are investigated due to change of heat collecting surface, heat storage method, capacity, building insulation performance and so on. Furthermore, it presents an improvement plan that maximizes the effect of the system and the performance of the system. In particular, this study examined the effect of solar heat using water bottles that can achieve a large thermal storage effect at low cost. Simulation results show that the proposed system reduces annual heating and hot water load by $17.9 \%$ compared to conventional systems.
\end{abstract}

\section{Introduction}

Solar energy is essentially an intermittent, time-dependent energy source. Due to the nature of the use of solar heat that only weekly heat can be collected, there is a difference between the heatable time and the time of heating load and hot water load. These offsets and intermittency complicate the use of solar energy. In other words, heat storage is necessary for effective use of solar energy.

In the case of the air-based solar heat system, since the heat capacity of air is small, it is necessary to store the heat by heat exchange with the material of the large heat capacity. There are a number of studies that attempt to solve daily-scale offsets (day-night) and annual-scale offsets (summer-winter) through various regenerative methods.

In order to solve the offset of the annual scale, a lot of costs (for example, a large-scale heat storage tank) is required, so in this study, a method of compensating the offset of the daily scale is examined. The daily-scale offsets are relatively easy to compensate with water tanks or other short-term storage methods (eg, utilizing the thermal mass of the building). Recently, there are many studies that use PCM (Phase Change Material) to store heat in the form of latent heat. Although the effect has been proven in many studies, the possibility of applying it to real houses is unknown due to cost problems. In this study, it is proposed a heating and hot water system for a house using air-based solar collection using foundation concrete and a space between the floor and foundation (placing plastic bottles with water) as a heat storage medium.

In order to maximize the performance of the solar heating system, it is necessary to consider the overall heat balance of the thermal characteristic change of the whole building by applying each elemental technology. In this research, the air-based solar heating system is modeled and the validity of simulation model examined through comparison with experiment result. In addition, the performance of existing solar heating system is analyzed by annual simulation and the problems and the effect of thermal characteristics of the system are investigated due to change of heat collecting surface, heat storage method, capacity, building insulation performance and so on. Furthermore, it presents an improvement plan that maximizes the effect of the system and the performance of the system.

\section{Simulation conditions}

The simulation (ExTLA, Excel-based Thermal Load Analysis) used in this study is a thermal load calculation tool developed in the MAE laboratory of the University of Tokyo (Fukumoto, 2011). It calculates the convergence of simultaneous equations by Gauss-Seidel method using circular reference and iterative calculation function of Microsoft Office Excel. It is a feature of Excel-based simulation that it is possible to input mathematical formulas to each cell and to refer to the values of other cells from users. In the calculation method of ExTLA, it is adopted that a thermal network calculation in which the indoor temperature, the room humidity, the surface temperature of the indoor, the wall body temperature and so on. The backward difference of finite-difference methods was applied for the calculation of unsteady-state thermal conduction of the wall. The calculation is made in which convection and radiation are separated in the heat balance of the indoor surface.

An annual simulation was conducted to grasp the performance of the air-based solar heating system. The target building is a standard house prescribed by "Japanese energy saving standard (next generation energy saving standard)", and the interior space was divided into a heating space and a non-heating space. In order to secure the heat collecting area, the roof surface was set as the south-facing inclined surface, and the inclination angle of the roof surface and the heat collector was set as the latitude of Tokyo $\left(35 \cdot 4^{\circ}\right)$. Also, assuming the surrounding buildings, we set the solar transmittance of the window to 
zero on the first floor so that there is no solar radiation acquisition from the window. Fig. 1 and Table 1 show building information. In this simulation, we were targeting a standard 4-person family, and assumed 450L/day hot water consumption (corrected M1 mode at $40^{\circ} \mathrm{C}$ by hot water supply) of Institute for Building Environment and Energy Conservation (2007).

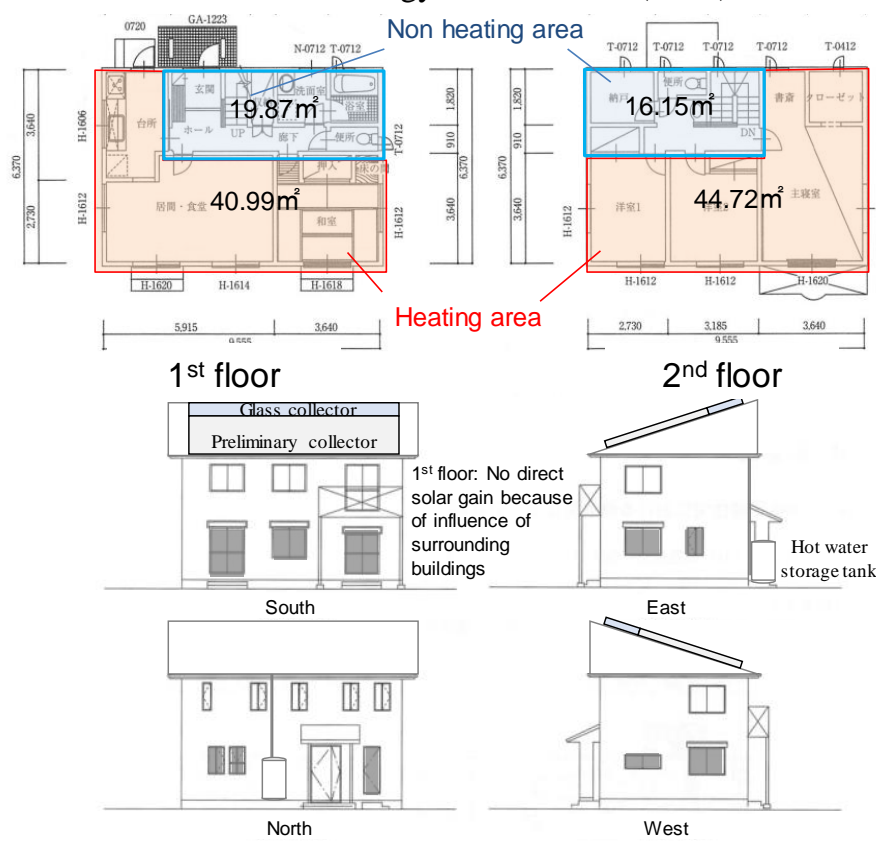

Figure 1: Target building.

Table 1: Specification of target building.

\begin{tabular}{|c|c|}
\hline Area & $\begin{array}{l}\text { Whole floor area: } 121.73 \mathrm{~m}^{2} \\
\text { Heating area of 1st floor: } 40.99 \mathrm{~m}^{2}, \\
\text { Non heating area of 1st floor: } 19.87 \mathrm{~m}^{2} \\
\text { Heating area of 2nd floor: } 44.72 \mathrm{~m}^{2}, \\
\text { Non heating area of 2nd floor: } 16.15 \mathrm{~m}^{2}\end{array}$ \\
\hline Volume & $328.06 \mathrm{~m}^{3}$ (including underfloor space) \\
\hline $\begin{array}{l}\text { Insulation } \\
\text { of each part }\end{array}$ & $\begin{array}{l}\text { Ceiling: glasswool } 18 \mathrm{~K} \mathrm{t}=210 \mathrm{~mm} \\
\text { Wall: glasswool } 16 \mathrm{~K} \mathrm{t}=100 \mathrm{~mm} \\
\text { Roof: glasswool } 32 \mathrm{~K} \mathrm{t}=50 \mathrm{~mm} \\
\text { Basis concrete: Extruded polystyrene foam } \\
\mathrm{t}=50 \mathrm{~mm}\end{array}$ \\
\hline Window & $\begin{array}{c}\text { Plain double-glazed glass (Uw: } \\
\left.4.65 \mathrm{~W} / \mathrm{m}^{2} \mathrm{~K}\right)\end{array}$ \\
\hline $\begin{array}{c}\text { Overall } \\
\text { coefficient of } \\
\text { heat transfer }\end{array}$ & UA-value: $0.83 \mathrm{~W} / \mathrm{m}^{2} \mathrm{~K}$ \\
\hline $\begin{array}{c}\text { Surface heat } \\
\text { transfer rate of } \\
\text { hot water tank }\end{array}$ & $\begin{array}{l}0.70 \mathrm{~W} / \mathrm{m}^{2} \mathrm{~K} \text { (Insulation: } 50 \mathrm{~mm} \text {, Thermal } \\
\text { conductivity: } 0.036 \mathrm{~W} / \mathrm{mK} \text { ) }\end{array}$ \\
\hline
\end{tabular}

The area ratio of a preliminary collector and a glass collector was set to $3: 1$ as preliminary collector $45 \mathrm{~m}^{2}$ and glass collector $15 \mathrm{~m}^{2}$. The capacity of the hot water storage tank was set to 1000L. The tank surface heat transmission coefficient of $0.7 \mathrm{~W} / \mathrm{m}^{2} \mathrm{~K}$ was input assuming a thermal insulation material of $50 \mathrm{~mm}$ (Thermal conductivity 0.267 $\mathrm{W} / \mathrm{mK}$ ), and the heat loss was calculated from the difference between the outside air temperature and the temperature inside the tank. In addition, the length of heat collection side piping of the hot water storage tank was set to $30 \mathrm{~m}$ and the thermal conductivity was set to 0.267 $\mathrm{W} / \mathrm{mK}$, and the heat loss from the pipe to the outside air was taken into consideration by the previous study. Table 2 shows the simulation condition.

Table 2: Simulation condition.

\begin{tabular}{|c|c|}
\hline Weather data & $\begin{array}{c}\text { ExpandedAMeDAS standard year (2000) } \\
\text { Tokyo }\end{array}$ \\
\hline $\begin{array}{c}\text { Heating } \\
\text { setpoint }\end{array}$ & $20{ }^{\circ} \mathrm{C}$ \\
\hline $\begin{array}{c}\text { Heating } \\
\text { schedule }\end{array}$ & $7: 00-10: 00,12: 00-14: 00,16: 00-23: 00$ \\
\hline $\begin{array}{c}\text { Collector } \\
\text { inclination } \\
\text { angle }\end{array}$ & Latitude of Tokyo $\left(35.4^{\circ}\right)$ \\
\hline $\begin{array}{c}\text { Calculation } \\
\text { period }\end{array}$ & $\begin{array}{c}\text { Pre-calculation: January } 1^{\text {st }}-\text { April } 30^{\text {th }} \\
\text { Main calculation: May } 1^{\text {st }}-\text { April } 30^{\text {th }}\end{array}$ \\
\hline Time step & 1 hour \\
\hline $\begin{array}{c}\text { Hot water } \\
\text { consumption }\end{array}$ & $450 \mathrm{~L} /$ day $\left(40^{\circ} \mathrm{C}\right)$ \\
\hline $\begin{array}{c}\text { Internal heat } \\
\text { generation }\end{array}$ & $13.26 \mathrm{kWh} / \mathrm{day}^{\circ}$ \\
\hline $\begin{array}{c}\text { Collector area, } \\
\text { air volume }\end{array}$ & $\begin{array}{c}15 \mathrm{~m}^{2} \\
\text { preliminary collector: } 45 \mathrm{~m}^{2}, \mathrm{ass} \text { collector: } \\
\text { Air flow rate: } 780 \mathrm{~m}^{3} / \mathrm{h}\end{array}$ \\
\hline
\end{tabular}

\section{Modeling of solar collector}

By the calculation model of the air-based solar heat collector (Udagawa, 2009), the temperature of the heat medium of the collector and the heat collection intensity was calculated. As shown in Equations (1) and (2), the outlet temperature and heat collection intensity of the collector are calculated from the inlet temperature, the sol-air temperature, and the coefficient of heat transmission of the collector. The sol-air temperature corresponding to the collector is obtained from Equation (4) and Table 3.

$$
\begin{gathered}
T_{\text {fout }}=T_{\text {cole }}-\left(T_{\text {cole }}-T_{\text {fin }}\right) \exp \left(-K_{c} A_{c} / c_{f} G_{f}\right) \\
Q_{c}=c_{f} G_{f}\left(T_{\text {fout }}-T_{\text {fin }}\right)=c_{f} G_{f} \varepsilon_{c}\left(T_{\text {cole }}-T_{\text {fin }}\right) \\
\varepsilon_{c}=1-\exp \left(-K_{c} A_{c} / c_{f} G_{f}\right) \\
T_{\text {cole }}=k_{u} T_{\text {coleu }}+k_{d} T_{\text {coled }} \\
K_{c u}=K_{\text {su }} f_{c u}, K_{c d}=K_{s d} f_{c d} \\
f_{c u}=\alpha_{c} W_{s d} b_{12}+\alpha_{c} W_{s u} b_{22} \\
f_{c d}=\alpha_{c} W_{s d} b_{11}+\alpha_{c} W_{s u} b_{21} \\
b_{11}=\left(\alpha_{r}+\alpha_{c}+K_{s u}\right) / D e t, b_{12}=\alpha_{r} / D e t
\end{gathered}
$$

$b_{21}=\alpha_{r}\left(W_{s u} / W_{s d}\right) /$ Det,$b_{22}=\left(\alpha_{r} W_{s u} / W_{s d}+\alpha_{c}+K_{s d}\right) / D e t$

Det $=\left(\alpha_{r} A_{s u} / A_{s d}+\alpha_{c}+K_{s d}\right)\left(\alpha_{r}+\alpha_{c}+K_{s u}\right)-\alpha_{r}^{2}\left(A_{s u} / A_{s d}\right)(8)$

here,

$T_{\text {fout }} T_{\text {fin }}: \quad$ Outlet and inlet temperature of collector $\left[{ }^{\circ} \mathrm{C}\right]$

$T_{\text {cole }}: \quad$ Sol-air temperature of collector $\left[{ }^{\circ} \mathrm{C}\right]$

$K_{c}$ : $\quad$ Coefficient of heat transmission of the

collector $\left[\mathrm{W} / \mathrm{m}^{2} \mathrm{~K}\right]$

$A_{c}: \quad$ Collector area $\left[\mathrm{m}^{2}\right]$

$c_{f}: \quad$ Specific heat of air static pressure $[\mathrm{J} / \mathrm{kgK}]$ 


$\begin{array}{ll}G_{f}: & \text { Air volume }[\mathrm{kg} / \mathrm{s}] \\ Q_{c}: & \text { Heat collection intensity }[\mathrm{W}] \\ \mathcal{E}_{c}: & \text { Efficiency of Heat Exchanger in Collector } \\ & {[-]} \\ a_{c}: & \begin{array}{l}\text { Convective heat transfer rate on the } \\ \text { collector surface }\left[\mathrm{W} / \mathrm{m}^{2} \mathrm{~K}\right]\end{array} \\ a_{r}: & \text { Radiation heat transfer rate on the collector } \\ W_{s d}, W_{s u}: & \text { surface }\left[\mathrm{W} / \mathrm{m}^{2} \mathrm{~K}\right] \\ A_{s d}, A_{s u}: & \text { Width of Collector frontside and backside } \\ & \text { (area per unit length) }[\mathrm{m}]\end{array}$

Table 3. Parameters of air-based solar heat collector calculations.

\begin{tabular}{|c|c|c|c|c|c|c|c|}
\hline & $K_{s u}$ & $K_{s d}$ & $K_{c}$ & $T_{\text {coleu }}$ & $T_{\text {coled }}$ & $S G$ & $T_{\text {cole }}$ \\
\hline $\begin{array}{l}\text { Glass } \\
\text { collector }\end{array}$ & $\begin{array}{c}1 /\left(r_{a}+\right. \\
\left.1 / \alpha_{o}\right)\end{array}$ & & & $S G / K_{s l}$ & & $\begin{array}{c}\left(\tau_{g} a_{s u}\right. \\
I)_{e}\end{array}$ & $\begin{array}{c}k_{u}= \\
K_{c u} / K_{c}\end{array}$ \\
\hline $\begin{array}{l}\text { Prelimin } \\
\text { ary } \\
\text { collector }\end{array}$ & $\alpha_{o}$ & $1 / r_{b}$ & $\begin{array}{c}\Lambda_{c u}+ \\
K_{c d}\end{array}$ & $\begin{array}{c}R_{s k y c} / \alpha_{o}+ \\
T_{o}\end{array}$ & $T_{x}$ & $\left(a_{s u} I\right)_{e}$ & $\begin{array}{c}k_{d}= \\
K_{c d} / K_{c}\end{array}$ \\
\hline
\end{tabular}

\begin{tabular}{ll}
\multicolumn{1}{c}{ here, } & Thermal resistance of the hollow layer \\
$r_{a}:$ & {$\left[\mathrm{m}^{2} \mathrm{~K} / \mathrm{W}\right]$} \\
$a_{o}:$ & Surface heat transfer coefficient $\left[\mathrm{W} / \mathrm{m}^{2} \mathrm{~K}\right]$ \\
$r_{b}:$ & Thermal resistance of surface material \\
$R_{\text {skyc }}:$ & {$\left[\mathrm{m}^{2} \mathrm{~K} / \mathrm{W}\right]$} \\
$T_{o}:$ & Night radiation on the outside surface of the \\
$T_{X}:$ & collector $\left[\mathrm{W} / \mathrm{m}^{2}\right]$ \\
$\tau_{g}:$ & Outside temperature $\left[{ }^{\circ} \mathrm{C}\right]$ \\
$a_{s u}:$ & Collector backside temperature $\left[{ }^{\circ} \mathrm{C}\right]$ \\
$I:$ & Glass Transmission $[-]$
\end{tabular}

In order to examine the accuracy of the calculation model of the air-based solar heat collector, the outlet temperature of the collector of the experiment and simulation were compared under the same condition of the outside temperature, the inlet temperature, and the air volume. Fig. 2 shows the results for two days from December 19th to 20th 2012, when the preliminary collector area is $3.45 \mathrm{~m}^{2}$ and the glass collector area is $1.32 \mathrm{~m}^{2}$. Although there is a slight difference in temperature from the simulation, it is judged to be influenced by the temperature distribution on the backside surface of collectors and the measurement error of each equipment. However, in this study about the effect on the presence or absence of solar heat collector, it is considered that the accuracy of the simulation is sufficient.

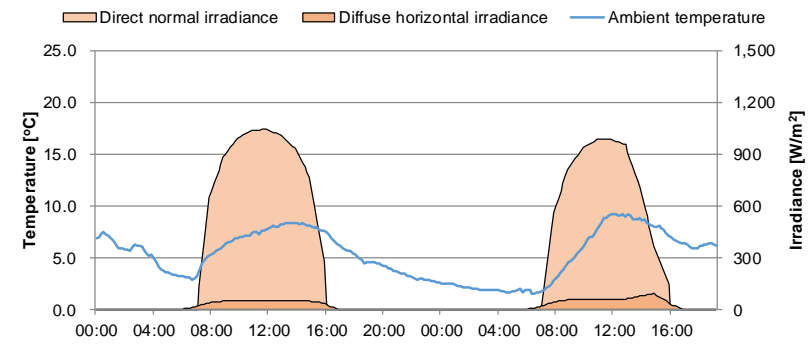

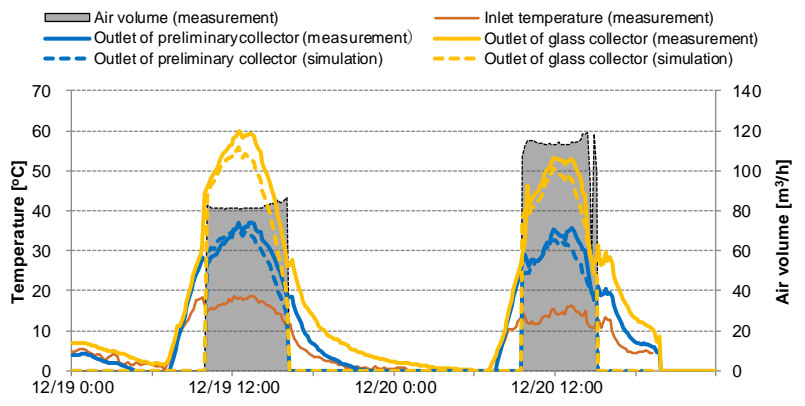

Figure 2: Examination of accuracy of air-based solar collector model (December $19^{\text {th }}$ to $20^{\text {th }}$, 2012).

Modeling of additional thermal storage (water pack)

In order to examine water packs in the underfloor space as additional thermal storage, a water pack calculationmodel was created based on the arrangement of the water packs at the time of the experiment. The method is to calculate the surface heat flow from the heat balance calculation-formula by the heat transfer on the surface of the water pack and the change in the temperature of the heat collection air, as shown in Equation (9). In addition, due to the characteristics of water, in order to calculate the convection by the internal temperature, calculations were made in three parts: upper, middle, and lower. In order to consider the temperature-change of the underfloor air due to heat absorption and heat release to the heat storage body, a calculation model was prepared by dividing the underfloor space and water pack (1000 L) into 12 spaces and 4 water packs. Furthermore, the change in the surface convective heat transfer coefficient due to the wind speed was input using the Jürges equation from Equation (10). The calculation model is shown in Fig. 3. Fig. 4 shows the pictures of underfloor insulation and additional thermal storage. The comparison between the calculated result and the experimental value is shown in Fig. 5. The underfloor air temperature, the internal temperature of the water pack, and the air temperature under the water pack differ by up to $2{ }^{\circ} \mathrm{C}$ or less. This difference is based on the assumption that the air is uniformly distributed in the simulation, and it is thought that the surface temperature actually changes according to the air flow. However, the variation of temperature is similar to the actual case, and it is considered that there is no problem in the examination according to the presence or absence of the water pack in this study.

$$
\begin{array}{cl}
c \rho V\left(d T_{a i} / d t\right) & =A \times \alpha_{c} \times\left(T_{s i}-T_{a i}\right)+c \rho V\left(T_{a i-1}-T_{a i}\right)(9) \\
\text { where, } & \\
T_{s i}: & \text { Surface temperature of thermal storage }\left[{ }^{\circ} \mathrm{C}\right] \\
T_{a i}: & \text { Air temperature }\left[{ }^{\circ} \mathrm{C}\right] \\
T_{a i-1}: & \text { Inflow air temperature }\left[{ }^{\circ} \mathrm{C}\right] \\
A: & \text { Surface area }\left[\mathrm{m}^{2}\right] \\
V: & \text { Air volume }\left[\mathrm{m}^{3} / \mathrm{h}\right] \\
C p: & \text { Specific heat of constant pressure of air }[\mathrm{J} / \mathrm{kgK}] \\
a_{c}: & \text { Convective heat transfer coefficient }\left[\mathrm{W} / \mathrm{m}^{2} \mathrm{~K}\right] \\
& \quad \alpha_{c}=5.6+3.9 v .
\end{array}
$$

where $\alpha_{c}$ is the convective heat transfer coefficient $\left[\mathrm{W} / \mathrm{m}^{2} \mathrm{~K}\right]$ and $v$ is the wind velocity $[\mathrm{m} / \mathrm{s}]$. 

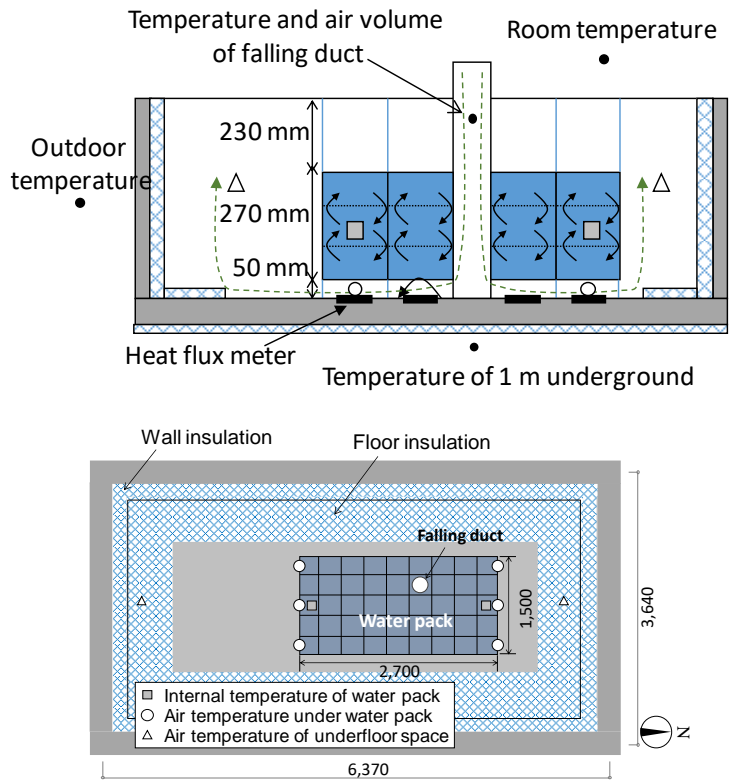

Figure 3: Water pack calculation model concept diagram.

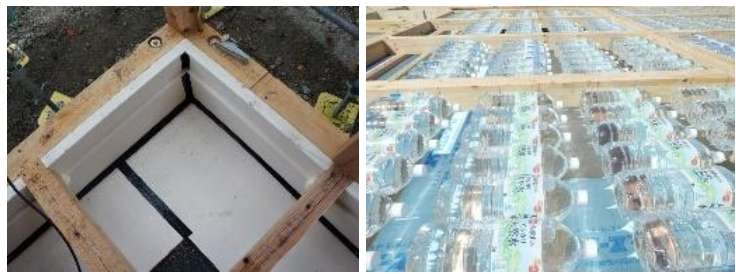

Figure 4: Pictures of underfloor insulation and additional thermal storage.
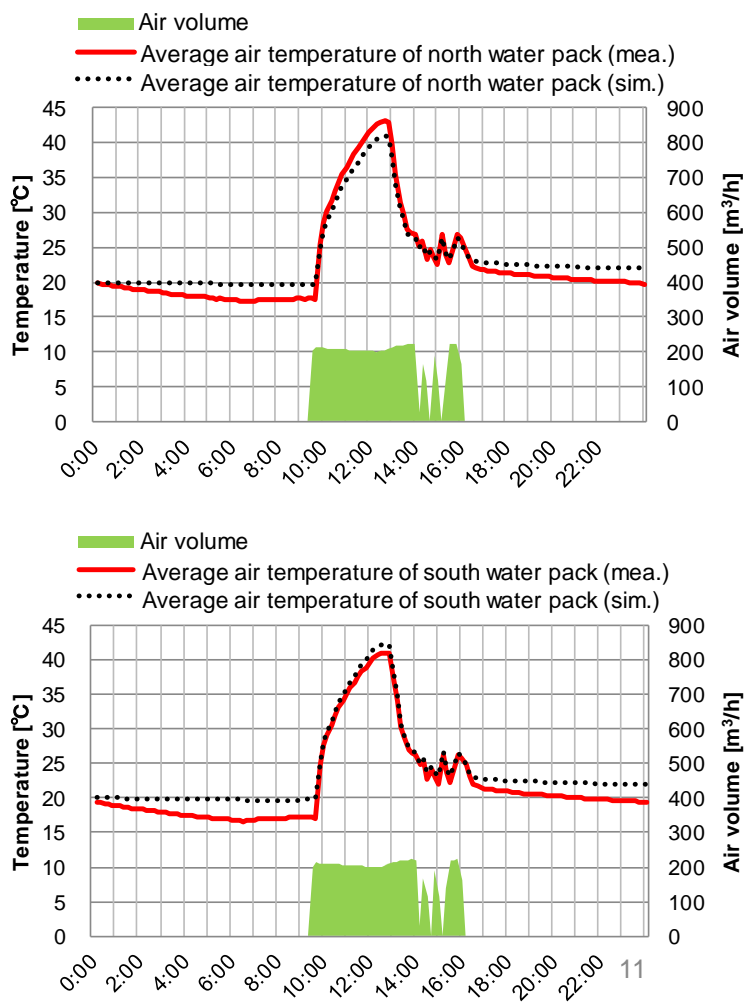

Figure 5: Evaluation of water pack calculation model for accuracy (January 28, 2013).
Understanding the performance of the solar heating system

\section{Simulation result of the typical house (non-solar heating collection)}

In order to examine the effect of load reduction by application of solar thermal system, we first conducted an annual simulation of a typical house without a heat collecting system installed. In order to confirm the time series fluctuation of room temperature and load at a typical house, we show the result of 5 days of sunny weather that the solar thermal utilization is possible during January when the annual outside temperature is low. Fig. 6 shows the direct solar radiation from January 7 th to 11 th (5 days) and the direct solar radiation and the sky solar radiation intensity on the heat collecting surface (south, inclination angle $35.4^{\circ}$ ). As shown in Fig. 7, the temperature in the room during the period (January 7 th to 11 th) is always lower than the heating set temperature $\left(20^{\circ} \mathrm{C}\right)$ in the first-floor heating room where there is no solar radiation from the window. The Heating load is generated by raising the room temperature to $20^{\circ} \mathrm{C}$ by auxiliary heating during heating time. On the contrary, in the second-floor heating room, the room temperature rises to $20^{\circ} \mathrm{C}$ or more due to the influence of the solar radiation from the window during the daytime, but the room temperature has dropped from the evening when the solar radiation acquisition disappears and the auxiliary heating operation is carried out.

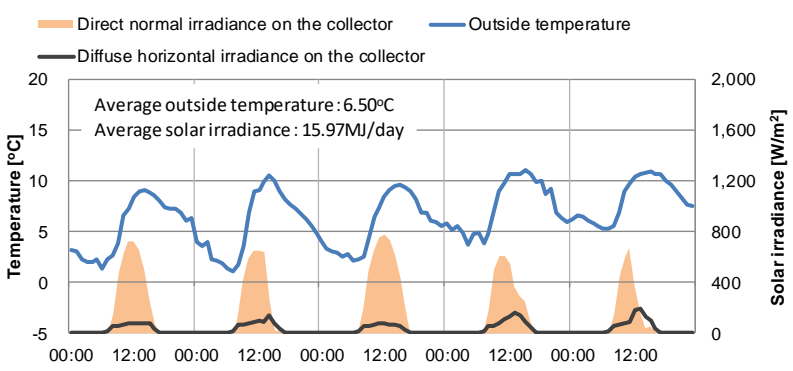

Figure 6: Weather conditions (January 7th - 11th).

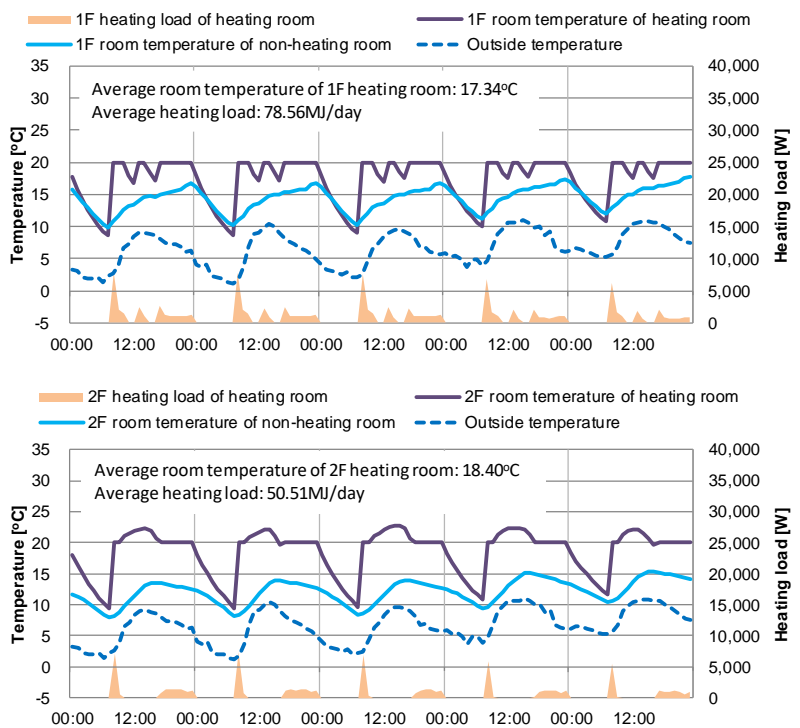

Figure 7: Room temperature results of a typical house. 


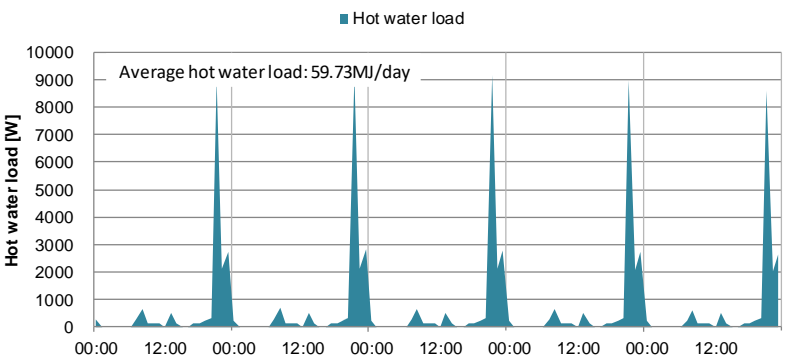

Figure 8: Hot water supply load of typical house.

Fig. 8 shows the hot water supply load by the auxiliary heat source during the examination period. A load of $8,612 \mathrm{~W}$ to $9,167 \mathrm{~W}$ is generated at 21 o'clock when the usage amount becomes maximum, and a hot water supply load of about $59.73 \mathrm{MJ}$ per day occurs on January 7 th to 11 th.

\section{Study on air-based solar heating system}

In order to improve the performance of the air-based solar heat collecting system, we examined the effect of annual heating and hot water supply load reduction by changing heat absorption/heat release of the heat collector, heat storage, and control of heat collection operation control. Regardless of the angle of the roof surface, the area ratio of the preliminary collector to the glass heat collector is set to $3: 1$ based on the floor area where the minimum area is secured, and the preliminary collectors $45 \mathrm{~m}^{2}$, Glass collector $15 \mathrm{~m}^{2}$ was set. Fig. 9 shows the operation control of the system. First, the seasons are determined based on the ambient temperature at 5:00 am, and heating, hot water supply, indoor circulation, and shutdown are judged based on room temperature, the outlet temperature of the collector, the temperature of the underfloor and so on.

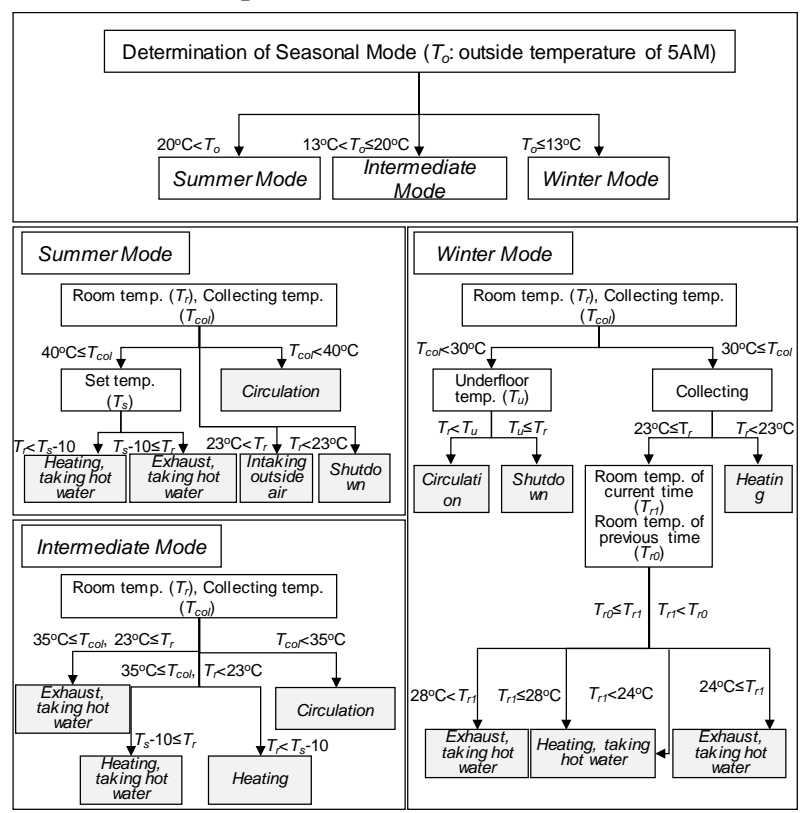

Figure 9: Operation control of the air-based solar heat collecting system.

Fig. 10 shows a conceptual diagram of the air-based solar heat collecting system to be studied in this research (Choi, 2018). By applying the air-based solar heating system, room temperature rises by blowing the heated air during the day into the room as shown in Fig. 11. In the case of the first-floor heating room, the average room temperature increased from $17.34{ }^{\circ} \mathrm{C}$ to $19.44{ }^{\circ} \mathrm{C}$-i.e., by about $2.1^{\circ} \mathrm{C}$-and the heating load was reduced by $42.5 \%$ from $78.56 \mathrm{MJ}$ per day to $45.21 \mathrm{MJ}$ per day. In the case of the second-floor heating room, the indoor temperature increased from $18.4{ }^{\circ} \mathrm{C}$ to $19.5{ }^{\circ} \mathrm{C}$ and the heating load decreased by about $18.6 \%$ from $50.51 \mathrm{MJ}$ per day to 41.14 MJ per day. It is considered that the effect of reducing the load on the first floor is larger because the original heat load of the second floor is not large due to the solar radiation, and the heated air first flows into the first floor. At that time, the temperature inside the hot water storage tank (Fig. 12) according to the hot water storage mode reaches a maximum of about $35^{\circ} \mathrm{C}$.
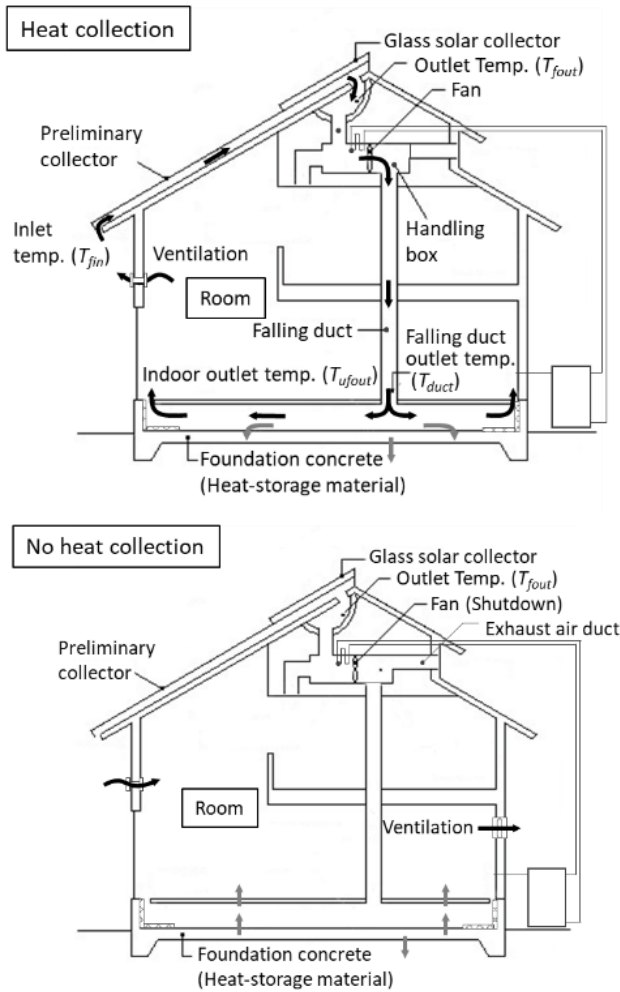

Figure 10: Conceptual diagram of the air-based solar heat collecting system.

Fig. 13shows the entrance and the exit temperature of the collector and the heat collection efficiency from January 7 th to 11 th when the air-based solar heating system is applied. Fig. 14 shows heat flux due to heat collection of air-based solar system. In order to increase the heating load reduction effect of the air-based solar heating system, it is important not only to improve the performance of the heat collector but also to increase the heat absorption performance of the heat storage. The heat storage helps that overheating in the daytime will not occur and that room temperature will not decrease by sufficiently dissipating the absorbed heat at night. In addition, it can be considered that it is possible to increase the annual heating and hot water supply load reduction effect by adjusting the hot water supply control according to the heating condition. Table 4 shows the load reduction effect by application of the air-based solar heating system. 


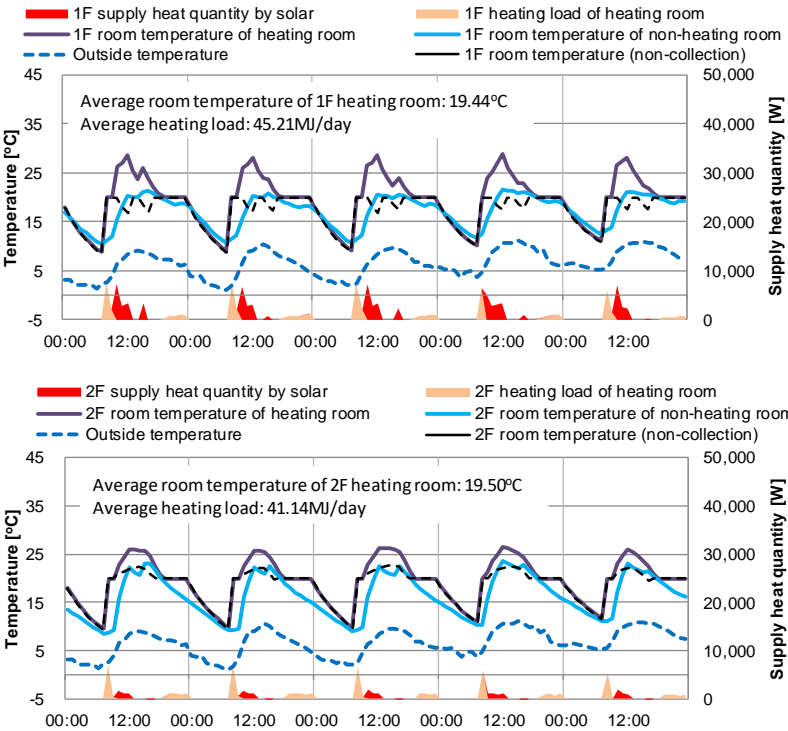

Figure 11: Room temperature results of air-based solar system.

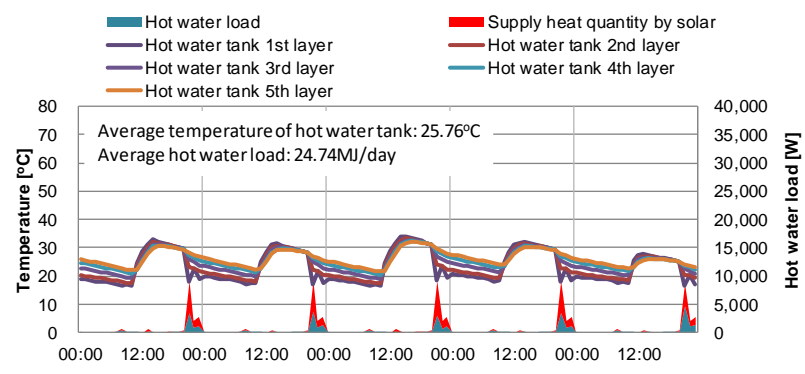

Figure 12: Temperature inside hot water storage tank.

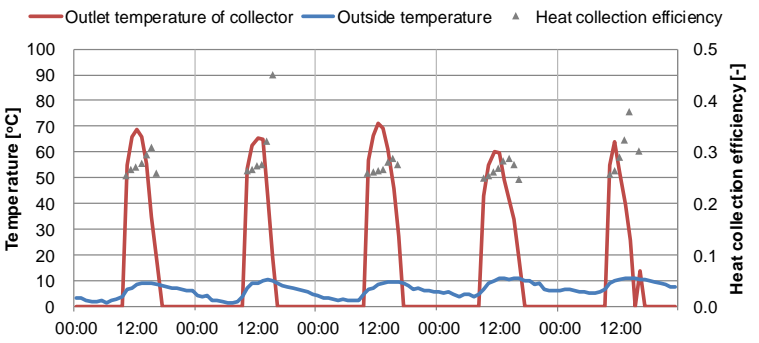

Figure 13: Outlet temperature of collector and heat collection efficiency.
Table 4: Load reduction effect by application of the airbased solar heating system.

\begin{tabular}{|c|c|c|c|c|c|}
\hline & $\begin{array}{c}\text { 1F } \\
\text { heating } \\
\text { Load } \\
\text { [GJ] }\end{array}$ & $\begin{array}{c}\text { 2F } \\
\text { heating } \\
\text { Load } \\
\text { [GJ] }\end{array}$ & $\begin{array}{c}\text { Hot } \\
\text { water } \\
\text { Load } \\
\text { [GJ] }\end{array}$ & $\begin{array}{c}\text { Reduction } \\
\text { of heating } \\
\text { load } \\
\text { [GJ] }\end{array}$ & $\begin{array}{c}\text { Reduction } \\
\text { of hot } \\
\text { water load } \\
\text { [GJ] }\end{array}$ \\
\hline $\begin{array}{c}\text { Typical } \\
\text { house }\end{array}$ & 9.72 & 6.92 & 15.87 & - & - \\
\hline $\begin{array}{c}\text { Air- } \\
\text { based } \\
\text { solar } \\
\text { heating } \\
\text { system }\end{array}$ & 5.67 & 5.58 & 5.55 & 5.39 & 10.32 \\
\hline
\end{tabular}

\section{Improvement plan for the air-based solar heating system}

First, the glass of the collector is changed to a Low-E glass as a method of reducing the heat loss of the solar collector (case 1). It is thought that although the glass transmittance is slightly reduced due to the change of the glass, the heat resistance of the glass is increased and the heat loss to the atmosphere is reduced. Next, as a method of increasing the heat radiation amount of the thermal storage, a heat insulating material is installed below the base concrete (case 2).

Table 5: Simulation cases of air-based solar heating system.

\begin{tabular}{|c|c|}
\hline Case1 & $\begin{array}{c}\text { Changing the glass of collector } \\
\text { Existing glass: Solar radiation transmittance } 0.88 \text {, } \\
\text { U-value } 6.0 \mathrm{~W} / \mathrm{m}^{2} \mathrm{~K} \\
\text { Low-E glass: Solar radiation transmittance } 0.74 \text {, } \\
\text { U-value } 2.7 \mathrm{~W} / \mathrm{m}^{2} \mathrm{~K}\end{array}$ \\
\hline Case2 & Case $1+$ insulation under base concrete \\
\hline Case3 & $\begin{array}{l}\text { Case } 2+\text { indoor circulation during non-solar heat } \\
\text { collection }\end{array}$ \\
\hline Case4 & $\begin{array}{l}\text { Case } 3+\text { additional thermal storage } \\
\text { (20L water packs } 3000 \mathrm{~L})\end{array}$ \\
\hline Case5 & $\begin{array}{l}\text { Case } 3+\text { additional thermal storage } \\
(500 \mathrm{ml} \text { plastic bottles } 3000 \mathrm{~L})\end{array}$ \\
\hline
\end{tabular}

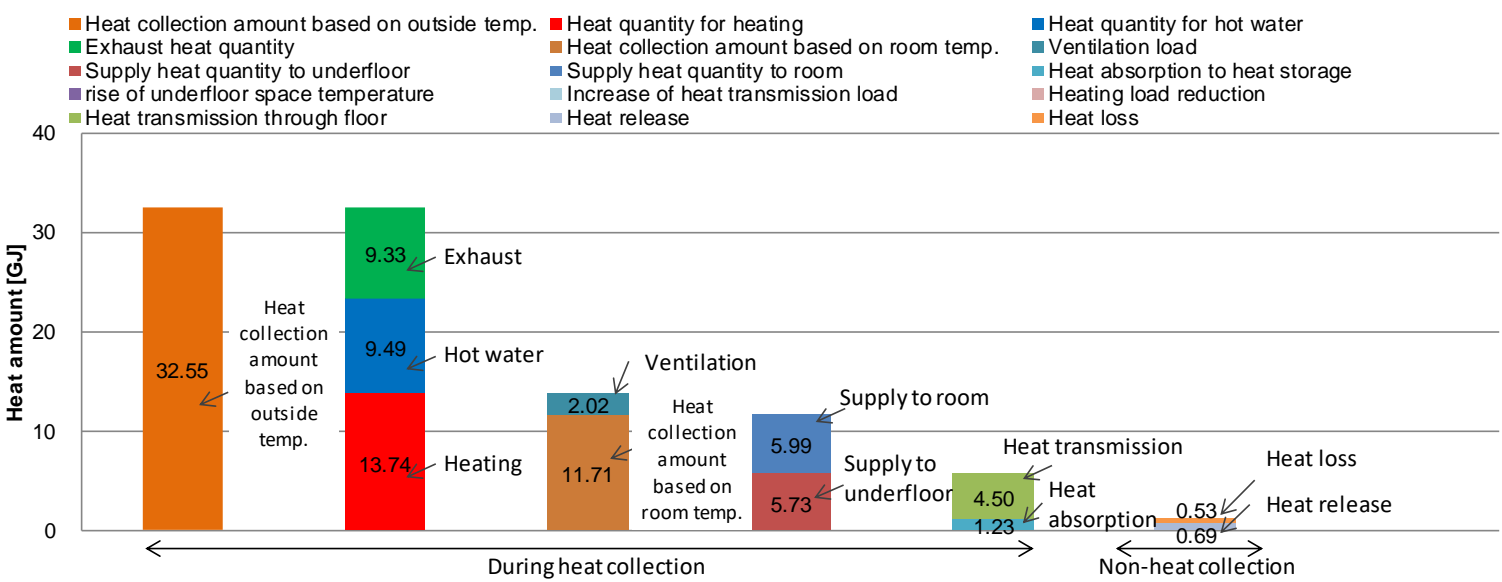

Figure 14: Heat flow due to heat collection of air-based solar system. 
This is believed to reduce the loss of heat absorbed in the base concrete to the ground. In addition, as a method for releasing the heat from thermal storage, the indoor air is forcedly convected to increase the heat transfer coefficient of the surface (case 3 ). Since the base concrete has a limited installation area and heat capacity as a thermal storage, the additional $20 \mathrm{~L}$ water packs are installed in the underfloor space to increase the heat capacity (case 4). In order to enlarge the surface of the additional thermal storage, the $500 \mathrm{ml}$ water bottles are used instead of 20L (case 5). Table 5 show the simulation cases. The annual simulation results of the improvement of the air-based solar heat collection system are shown in Table 6 . For the condition of the buildings, weather data, and system conditions of this study, $48.3 \%$ of heating and hot water load was reduced annually due to the application of the conventional air-based solar heat collection system. Also, by replacing the glass in the collector with Low-E, it was found that the heating load of the system can be reduced by about $2.5 \%$ compared to the existing system. Insulation below the base concrete resulted in a load reduction of about $0.2 \%$. However, when the additional thermal storage is installed, the temperature of the underfloor space rises and the effect of the heat insulation is expected to increase. Lastly, it was shown that installing $3000 \mathrm{~L}$ of $500 \mathrm{ml}$ plastic bottles with additional thermal storage can save the annual load up to $66.5 \%$ and keep the room temperature constant.

Table 6: Load reduction effect.

\begin{tabular}{|c|c|c|c|c|c|c|}
\hline & \multirow{2}{*}{$\begin{array}{c}\text { Heating } \\
\text { load of } \\
\text { 1st floor } \\
\text { [GJ] }\end{array}$} & \multirow{2}{*}{$\begin{array}{c}\text { Heating } \\
\text { load of } \\
\text { 2nd floor } \\
\text { [GJ] }\end{array}$} & \multirow{2}{*}{\begin{tabular}{|c|} 
Hot \\
water \\
load \\
[GJ]
\end{tabular}} & \multirow{2}{*}{$\begin{array}{c}\text { Load } \\
\text { Reducti } \\
\text { on ratio } \\
{[\%]}\end{array}$} & \multicolumn{2}{|c|}{ 1st floor } \\
\hline & & & & & $\begin{array}{l}\text { Avg. } \\
\text { Temp } \\
{\left[{ }^{\circ} \mathrm{C}\right]}\end{array}$ & $\begin{array}{c}\text { Daily } \\
\text { differen } \\
\text { ce }\left[{ }^{\circ} \mathrm{C}\right]\end{array}$ \\
\hline $\begin{array}{l}\text { Non heat } \\
\text { collection }\end{array}$ & 9.72 & 6.92 & 15.87 & & & \\
\hline $\begin{array}{c}\text { Existing } \\
\text { system }\end{array}$ & 5.67 & 5.58 & 5.55 & $48.3 \%$ & 20.2 & 14.6 \\
\hline Case1 & 5.31 & 5.49 & 5.20 & $50.8 \%$ & 20.2 & 14.8 \\
\hline Case2 & 5.29 & 5.47 & 5.18 & $51.0 \%$ & 20.2 & 14.8 \\
\hline Case3 & 3.62 & 4.77 & 5.59 & $57.0 \%$ & 20.7 & 11.1 \\
\hline Case4 & 3.32 & 4.59 & 5.81 & $57.8 \%$ & 20.8 & 10.0 \\
\hline Case5 & 0.93 & 2.76 & 7.30 & $66.2 \%$ & 21.8 & 4.1 \\
\hline
\end{tabular}

\section{Conclusion}

As a result, the annual load has reduced by about $17.9 \%$ over the conventional air-based solar collection system. In this study, the improvement plan including various improvement factors was examined as a method to maximize the performance of the solar thermal system. However, the improvement of the indoor thermal environment by each factor and the examination of the load reduction effect are examined in the future.

In this study, the performance of existing air-based solar heat collection system was evaluated. In addition, an annual simulation was conducted to examine the improvement effect for reducing the annual heating load and the hot water supply load. In order to improve the airbased solar collecting system, the glass of the solar collector was changed from ordinary glass to Low-E glass with less heat loss, and thus the effect of increasing the amount of solar heat collection and reducing the annual load was examined. In order to increase the amount of heat releasing by the thermal storage, it was examined to install insulation at the bottom of the base concrete. It was investigated the effects of forced circulation (indoor circulation) of room air and underfloor air to increase the amount of heat dissipation from the thermal storage during non-solar heat collection, and additional heat storage to increase the heat capacity of the floor space. In this study, improvement proposals that included various elements were reviewed as methods of maximizing the performance of solar heating systems.

As suggested in this study, it is shown that the load reduction effect of air-based solar heating system can increase by putting low-cost water plastic bottles without a special system for thermal storage.

\section{References}

T.S.Ge, R.Z.Wang, Z.Y.Xu, Q.W.Pan, S.Du, X.M.Chen, T.Ma, X.N.Wu, X.L.Sun, J.F.Chen (2018). Solar heating and cooling: Present and future development. Renewable Energy 126, 1126-1140.

Jessica Settino, Tonio Sant, Christopher Micallef, Mario Farrugia, Cyril Spiteri Staines, John Licari, Alexander Micallef (2018). Overview of solar technologies for electricity, heating and cooling production, Renewable and Sustainable Energy Reviews 90, 892909.

Choi Y, Takase K, Mae M (2018). System performance of a residential building using the air-based solar heating system. Solar Energy 171(1), 47-63.

Fukumoto M (2011). Research on performance comparison and optimal operation in solar heating for different types of detached houses. MS thesis. Department of Architecture Engineering, The University of Tokyo. Tokyo, Japan.

Housing - Building Energy Conservation Organization (2006). Building Energy Conservation Standards and Calculation Handbook.

Institute for Building Environment and Energy Conservation (2007). Design Guidelines for Low Energy Housing with Validated Effectiveness.

Ito K, Sakabe Y, Tatematsu K, Murata S, Kitadani Y, Suzuki H, Aiso K, Matsumoto T, Mae M, Iwamae A (2010). Technological Development for Energy Generation Systems Using Roof Integrated HighEfficiency Vacuum Thermal Energy/Load Responsive Storage Etc. No.1 : Estimate for whole system performance based on individual performance tests of the developed solar hot water system parts. Summaries of technical papers of annual meeting, Architectural Institute of Japan, 171-172 
Mae M, Akamine Y, Kono R, Amano N, Matsueda N, Kawashima N, Kaihoh K (2011). Development of heating and cooling system utilizing solar and earth heat for detached houses Part1: Concept of the energy saving heating and cooling system and condition of measurement in experimental house. Summaries of technical papers of annual meeting, Architectural Institute of Japan, 1077-1078.

Matsueda N, Mae M, Akamine Y, Kono R, Amano N, Kawashima N, Kaihoh K (2011). Development of heating and cooling system utilizing solar and earth heat for detached houses : Part2: Influence on air- conditioning energy by insolation cover and earth heat of summer in residence type experiment house. Summaries of technical papers of annual meeting, Architectural Institute of Japan, 1079-1080.

Tanaka S (1977). Solar heating and cooling system. Ohmsha.

Tanaka S (1985). The latest architectural environmental engineering, Inoueshoin.

Udagawa M (1986). Calculation method of air conditioning by personal computer. Ohmsha.

Udagawa M (2009). Simulation model of solar energybased building sheath. JSES / JWEA Res. Present. 